\title{
SELECTION OF PURIFICATION CONDITION FOR RECOMBINANT ENDOGLUCANASE ORIGINATED FROM GOAT RUMEN BACTERIA IN Escherichia coli
}

\author{
Nguyen Thi Quy ${ }^{1}$, Nguyen Hong Duong ${ }^{1}$, Dao Trong Khoa ${ }^{1}$, Nguyen Khanh Hoang Viet ${ }^{2}$, \\ Nguyen Khanh Hai ${ }^{3}$, Truong Nam Hai ${ }^{1,4, *}$, Do Thi Huyen ${ }^{1,4, *}$ \\ ${ }^{1}$ Institute of Biotechnology, VAST, Vietnam \\ ${ }^{2}$ Institute of New Technology, Academy of Military Science and Technology \\ ${ }^{3}$ Faculty of Biology, VNU Hanoi University of Science \\ ${ }^{4}$ Graduate University of Science and Technology, VAST, Vietnam
}

Received 10 October 2019, accepted 2 March 2020

\begin{abstract}
Cellulase is an important enzyme that plays a role in cleaving $\beta-1,4$ glucoside on cellulose to release glucose, which is of economic value and can be applied in many different fields. The $1545 \mathrm{bp}$ endoglucanase gene mined from goat rumen's bacterial metagenomic data was expressed in Escherichia coli Rosetta2. In this study, the recombinantendoglucanase was purified by his tag affinity chromatography with differrent processes, such as using phos phate buffer with or without sodium cloride, pretreatment of samples with ammonium sulphate before supplying into affinity column, using various concentration of imidazole for washing... Finally the endoglucanse was sucessfully purified by his-tag affinity column using sodium chloride-free phosphate buffer of which $150 \mathrm{mM}$ and $400 \mathrm{mM}$ imidazole were used for washing and enzyme elution, respectively. The resulting enzyme showed its high purity of $99 \%$. CMC plate assay confirmed that although less active than commercial cellulase (Sigma), the recombinant cellulase hydrolyzed CMC to form a clear zone (halo) around the well. The purified enzyme is capable of using as material for further analysis.
\end{abstract}

Keywords: Escherichia coli Rosetta2, Carboxymethylcellulose (CMC), clear zone (halo), protein purification, recombinant endoglucanase.

Citation: Nguyen Thi Quy, Nguyen Hong Duong, Dao Trong Khoa, Nguyen Khanh Hoang Viet, Nguyen Khanh Hai, Truong Nam Hai, Do Thi Huyen, 2020. Selection of purification condition for recombinant endoglucanaseorigin ated from goat rumen bacteria in Escherichia coli. Tap chi Sinh hoc, 42(1): 73-81. https://doi.org/10.15625/0866$7160 / \mathrm{v} 42 \mathrm{n} 1.14455$.

*Corresponding author email: dohuyen@ibt.ac.vn

(2020 Vietnam Academy of Science and Technology (VAST) 


\title{
LỬA CHỌN ĐIỀU KIỆN TINH CHẾ ENDOGLUCANASE TÁI TỔ HỢP CÓ NGUỔN GỐC TƯ VI KHUẨN DẠ CỎ DÊ Ở TẾ BÀO Escherichia coli
}

\author{
Nguyễn Thị Quý' ${ }^{1}$, Nguyễn Hồng Dương ${ }^{1}$, Đào Trọng Khoa ${ }^{1}$, Nguyễn Khánh Hoàng Việt ${ }^{2}$, \\ Nguyển Khánh Hải ${ }^{3}$, Trương Nam Hải ${ }^{1,4, *}$, Đỗ Thị Huyền ${ }^{1,4, *}$ \\ 'Viện Công nghệ sinh học, Viện Hàn lâm Khoa học và Công nghệ Việt Nam \\ ²Viện Công nghệ mới, Viện Khoa học Kỹ thuật Quân sự \\ ${ }^{3}$ Khoa Sinh học, Trường Đại học Khoa học tự nhiên, Đại học Quốc gia Hà Nội \\ ${ }^{4}$ Học viện Khoa học và Công nghệ, Viện Hàn lâm Khoa học và Công nghệ Việt Nam
}

Ngày nhận bài 10-10-2019, ngày chấp nhận 2-3- 2020

\section{TÓM TẮT}

Cellulase là enzyme quan trọng cắt liên kết $\beta-1,4$ glucoside trên phân tử cellulose để giải phóng ra đường glucose, là chất có giá trị kinh tế và có thể ứng dụng trong nhiều lĩnh vực khác nhau. Gen mã hóa cho endoglucanase khai thác từ hệ vi khuẩn sống trong dạ cỏ dê có chiều dài 1545 bp đã được biểu hiện thành công trong Escherichia coli Rosetta2. Trong công trình này, endoglucanase tái tổ hợp đã được tinh chể bằng cột sắc ký ái lực với his-tag với các phương pháp khác nhau như sử dụng đệm phosphate có hoặc không có muối natri clorua, sơ chế mẫu với ammonium sulphate trước khi đưa mẫu lên cột, sử dụng các nồng độ khác nhau của imidazole trong quá trình rửa. Cuối cùng, endoglucanase đã được tinh chế thành công bằng cột sắc ký ái lực his-tag với đệm không có muối $\mathrm{NaCl}$, sử dụng imidazole $150 \mathrm{mM}$ cho phân đoạn rửa và enzyme được thu lại trong đệm chứa $400 \mathrm{mM}$ imidazole. Enzyme tái tổ hợp sau tinh chế có độ tinh sạch lên tới $99 \%$. Kết quả kiểm tra hoạt tính của cellulase tái tổ hợp trên đĩa thạch đã cho thấy mặc dù hoạt tính kém hơn cellulase thương mại (Sigma) nhưng enzyme đã thủy phân $\mathrm{CMC}$ tạo thành một vòng sáng quanh giếng. Enzyme tinh chế có thể được sử dụng làm nguyên liệu cho các nghiên cứu sâu hơn.

Từ khóa: Escherichia coli Rosetta2, Carboxymethylcellulose (CMC), endoglucanase tái tổ hợp, vòng thủy phân cơ chất, tinh sạch protein.

*Địa chỉ liên hệ email: dohuyen@ibt.ac.vn

\section{MỞ ĐẦU}

Cellulose là nguyên liệu sinh học có nguồn gốc tự nhiên dồi dào nhất và là thành phần chính của sinh khối thực vật. Việc sử dụng nguồn nguyên liệu này đem lại lợi ích kinh tế phần lớn phụ thuộc vào tốc độ thủy phân lignocellulose để tạo ra các chất trao đối và nhiên liệu sinh học như cồn sinh học thế hệ thứ hai, xilytol, glucose. Có ba loại enzyme chính tham gia vào việc thủy phân cellulose thành đường glucose đó là $\beta-1,4-$ endoglucanase; $\beta-1,4-$ exoglucanase và $\beta$ - glucosidase và cả một phứchệ các enzyme cellulase (Pandey et al., 2014). Enzyme $\beta-1,4-$ endoglucanase là một thành viên trong họ cellulase. Cellulase xúc tác thủy phân mối liên kết $\beta-1,4$ glucoside trên phân tử cellulose để giải phóng ra đường glucose. Đây là enzyme được nhiều nhà khoa học phân lập và xác định đặc điểm từ các đối tượng như vi khuẩn, nấm và động vật (Lynd et al., 2002). Trong đó, cellulase của vi khuẩn ngày càng được chú ý hơn do chúng có tốc độ sinh trưởng nhanh, tạo ra một phức hợp nhiều enzyme và chúng có khả năng sinh sống trong các điều kiện khắc 
nghiệt (Maki et al., 2009). Các nghiên cứu đã tập trung tìm kiếm các nguồn enzyme mới có tiềm năng sử dụng trong công nghiệp như cellulase của vi khuẩn sống trong ruột mối, dạ cỏ dê và các đối tượng khác. Việc tìm kiếm cellulase có hoạt tính cao, biểu hiện chúng ở trạng thái tan trong các hệ thống vật chủ và tinh sạch chúng có ý nghĩa quan trọng nhằm định hướng lựa chọn enzyme phù hợp trong công nghiệp.

Enzyme tạo ra từ các hệ thống vật chủ dùng cho mục đích xác định đặc điểm, nghiên cứu cấu trúc cần thiết được tinh sạch. Việc lựa chọn phương pháp tinh sạch chủ yếu phụ thuộc vào khả năng hấp phụ, khối lượng phân tử và đặc điểm của enzyme. Trong đó, sắc ký ái lực là kỹ thuật dựa vào khả năng liên kết đặc hiệu và thuận nghịch của một enzyme gắn với phối tử liên kết đồng hóa trị với chất mang chứa trong cột sắc ký. Ưu điểm của phương pháp này là cho phép thu được enzyme có độ sạch cao trong khoảng thời gian ngắn. Để sử dụng kỹ thuật này, enzyme được thiết kế có khả năng bám ái lực lên chất giá như gắn thêm đuôi his-tag vào đầu $\mathrm{N}$ hoặc đầu $\mathrm{C}$. Enzyme được giữ lại trên cột, còn những protein khác không có đuôi his-tag sẽ được rửa trôi. Cuối cùng, enzyme được thu lại bằng cách sử dụng đệm có nồng độ muối cao, thay đổi $\mathrm{pH}$ đệm. Các loại đệm phổ biến dùng cho sắc ký là tris, phosphate hoặc acetate có chứa từ $50-500 \mathrm{mM} \mathrm{NaCl}$. Tuy nhiên, hiệu quả bám của enzyme còn phụ thuộc vào thành phần đệm, $\mathrm{pH}$, đặc điểm của enzyme. Do đó, với mỗi loại enzyme cần có một phương pháp tinh chế phù hợp.

Trong bài báo này, chúng tôi trình bày kết quả của việc lựa chọn các điều kiện tinh chế enzyme endoglucanase tái tổ hợp có nguồn gốc từ vi khuẩn sống trong dạ cỏ dê đã được biểu hiện thành công ở tế bào Escherichia coli Rosetta2 (DE3) (Nguyen et al., 2019). Sau đó enzyme được loại muối và kiểm tra sơ bộ khả năng thủy phân cơ chất $\mathrm{CMC}$ (carboxymethylcellulose) trên đĩa thạch. Kết quả này là cơ sở cần thiết cho nghiên cứu đặc tính enzyme, xem xét khả năng ứng dụng enzyme trong thực tiễn.

\section{VÂT LIÊU VÀ PHƯƠNG PHÁP NGHIÊN CỦU}

Chủng Escherichia coli Rosetta2 tái tổ hợp mang vector pET22SUMOegc2 (Nguyen et al., 2019) do phòng Kỹ thuật di truyền, Viện Công nghệ sinh học tạo ra, được dùng để biểu hiện gen endoglucanase. Cột sắc ký ái lực HisTrap 5 mlvà cột PD-10 (Amersham Bioscience, Anh) lần lượt được sử dụng để tinh chế và loại muối cho mẫu endoglu can ase tái tổ hợp. CMC (C9481, Sigma) dùng làm cơ chất xác định hoạt tính của endoglucanase trên đĩa thạch. Cellulase (C9748, Sigma) được dùng làm đối chứng dương. Các hóa chất khác dùng trong thí nghiệm được mua của Merck (Đức) và Thermo Scientific (Hoa Kỳ).

\section{Tinh chế endoglucanase tái tổ hợp bằng sắc ký ái lực}

Sự biểu hiện của endoglucanase (EGC2) tái tổ hợp ở tế bào Escherichia coli Rosetta2 được tiến hành như Nguyen và đồng tác giả đã mô tả (Nguyen et al., 2019). Một cách ngắn gọn, dịch nuôi cấy qua đêm của chủng Escherichia coli tái tổ hợp được chuyển sang $200 \mathrm{ml}$ LBamp sao cho OD 600 ban đầu khoảng 0,1 . Khi mật độ tế bào $\mathrm{OD}_{600} \sim 0,4-0,6$, cảm ứng biểu hiện $\mathrm{EGC2}$ ở $25^{\circ} \mathrm{C}$ với nồng độ IPTG là $0,25 \mathrm{mM}$. Tế bào được thu lại sau 5 giờ để nghiên cứu tinh chế enzyme.

Chuyển $15 \mathrm{ml}$ dịch tế bào có $\mathrm{OD}_{600} \sim 10$ vào ống falcon loại $25 \mathrm{ml}$. Tiến hành phá tế bào bằng sóng siêu âm trong 9 phút. Ly tâm dịch phá tế bào 8.000 vòng/phút trong 10 phút, thu pha tan chứa EGC2. Dịch sau khi thu có thể được sử dụng trực tiếp để tinh chế enzyme theo phương pháp sau: Bơm toàn bộ $15 \mathrm{ml}$ dịch pha tan lên cột HisTrap $5 \mathrm{ml}$ trước đó đã cân bằng với đệm $\mathrm{PBS} 50 \mathrm{mM}(\mathrm{pH} 6,8)$ có chứa hoặc không chứa $500 \mathrm{mM} \mathrm{NaCl}$, và 20-50 mM imidazol. Thu dịch trong lúc bơm mẫu $(\mathrm{F})$ để kiểm tra mức độ bám của endoglucanase. Sau đó rửa protein tạp lần lượt bằng $50 \mathrm{ml}$ đệm $\mathrm{PBS}$ chứa imidazol có nồng độ là $50 \mathrm{mM}, 100 \mathrm{mM}$ hoặc $150 \mathrm{mM}$. Thu các dịch rửa để kiểm tra protein đi ra khỏi cột $\left(\mathrm{W}_{1}\right.$ và $\mathrm{W}_{2}$ ). Tiếp theo, đẩy EGC2 bám trên cột bằng $25 \mathrm{ml}$ đệm PBS chứa $400 \mathrm{mM}$ imidazol, thu chúng vào các ống Eppendorf ( $2 \mathrm{ml} /$ ống). Ngoài ra, dịch tế bào sau khi siêu âm được sơ 
chế bằng tủa phân đoạn với $\left(\mathrm{NH}_{4}\right)_{2} \mathrm{SO}_{4}$, sau đó tiếp tục tinh chế bằng cột sắc ký ái lực với histidin. Cuối cùng, cân bằng cột với $25 \mathrm{ml}$ đệm gắn mẫu trước khi tinh chế lần tiếp theo. Các phân đoạn chứa endoglucanase tinh sạch được gộp lại và loại muối bằng cột $\mathrm{PD}-10$ theo hướng dẫn của nhà sản xuất.

\section{Đánh giá độ sạch của endoglucanase tái tổ hợp bằng phần mềm Quantity One}

Đây là phần mềm online của Bio-Rad cho phép đánh giá độ tinh sạch của một mẫu protein được nhuộm màu. Nguyên lý của phương pháp là đánh giá độ tinh sạch thông qua lượng protein đích (độ đậm của băng protein đích) so với lượng protein tổng số (độ đậm của các băng protein) trong mỗi giếng. Mẫu enzyme sau khi tinh sạch được điện di trên gel polyacrylamide cùng với thang chu ẩn protein. Sau đó, gel được nhuộm bằng thuốc nhuộm comassie, rửa sạch và đưa lên máy scan để quét. Chế độ quét được cài đặt sao cho chất lượng ảnh tốt nhất. Sau đó, ảnh quét được đưa về chế độ đen trắng và chuyển vào phần mềm Quantity One version 4.6 (https://quantity-one.software.informer.com/ 4.6/). Bằng phần mềm này, lượng enzyme có trên giếng chạy được nhận biết và quét để định lượng tương đối với enzyme tông số thông qua độ đậm của các băng. Độ sạch của enzyme tái tổ hợp được tính bằng tỷ lệ giữa lượng protein đích trên lượng protein tổng số ở mỗi giếng.

\section{Kiểm tra sơ bộ hoạt tính thủy phân cơ chất} của endoglucanase trên đĩa thạch

Nhỏ $200 \mu$ dịch endoglucanase tinh sạch được loại muối vào một giếng của đĩa thạch chứa $0,5 \% \mathrm{CMC}$. Đồng thời nhỏ cùng một thể tích các mẫu đối chứng dương (cellulase của Sigma, 1U) và đối chứng âm (dịch phá từ tế bào không cảm ứng IPTG) vào các giếng còn lại. Sau khi ủ đĩa ở $37^{\circ} \mathrm{C}$ khoảng 24 giờ tạo điều kiện enzyme thấm sâu vào thạch và thủy phân cơ chất, đĩa được nhuộm với Congo red $0,1 \%$ rồi rửa lại bằng dung dịch $\mathrm{NaCl} 1 \mathrm{M}$.

\section{KẾT QUẢ VÀ THẢO LUẬN}

Gen mã hóa cho endoglucanase có nguồn gốc từ vi khuẩn dạ cỏ dê có chiều dài $1.545 \mathrm{bp}$ được tối ưu mã bộ ba (gen egc2), tổng hợp hóa học và đưa vào vector biểu hiện pET22SUMO. Enzyme endoglucanse (SEGC2) đã được biểu hiện thành công trong tế bào Escherichia coli Rosetta2 với khối lượng phân tử khoảng $70 \mathrm{kDa}$ (Nguyen et al., 2019). Trong nghiên cứu này, chúng tôi trình bày việc lựa chọn điều kiện để tinh chế enzyme tái tổ hợp và kiểm tra sơ bộ hoạt tính của enzyme trên cơ chất CMC.

Tinh chế SEGC2 bằng đệm phosphate có chứa $\mathrm{NaCl} 500 \mathrm{mM}$

Tinh sạch enzyme là quá trình phân tách enzyme đó từ một phức hợp protein trong các tế bào. Thông thường, quá trình tinh chế sẽ dựa vào kích thước protein, các đặc tính lý hóa hay tương tác ái lực của protein. Theo thiết kế, phía trước endoglucanse là protein SUMO có gắn 6 gốc histidine thuận tiện cho việc tinh chế bằng sắc ký ái lực. Tuy nhiên, hiệu quả tinh chế còn phụ thuộc vào đặc điểm protein, thành phần đệm, nồng độ muối, các bước tiền xử lý mẫu.

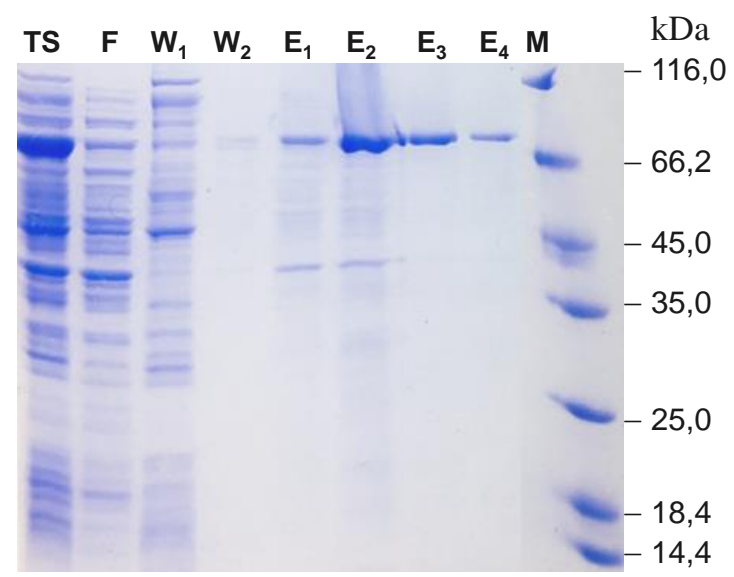

Hình 1. Ảnh điện di endoglucanase tinh chế bằng đệm phosphate chứa $500 \mathrm{mM} \mathrm{NaCl}$ sử dụng sắc ký ái lực với hexa-histidin

Ghi chú: TS: Protein tổng số pha tan; F: dịch thu trong khi bơm mẫu lên cột; $\mathrm{W}_{1}-\mathrm{W}_{2}$ : lần lượt là dịch rửa cột bằng đệm phosphate chứa 50 và 100 mM imidazol; $\mathrm{E}_{1}-\mathrm{E}_{4}$ : các phân đoạn thu mẫu ở nồng độ $300 \mathrm{mM}$ imidazol; M: thang protein chuẩn (Fermentas, SM0431)

Đệm phosphate có chứa $\mathrm{NaCl} 500 \mathrm{mM}$ đã từng được sử dụng để tinh chế rất thành công 
interleukin-11 (Nguyen et al., 2018). Đệm này được thử nghiệm để tinh chế endoglucanase, sử dụng đệm gắn, đệm rửa và đệm thu lần lượt có nồng độ imidazol là $50,100,300 \mathrm{mM}$. Kết quả cho thấy endoglucanase được thu lại với hàm lượng rất thấp và còn khá bẩn (hình 1 ). Lặp lại thí nghiệm này và sử dụng đệm phosphate $20 \mathrm{mM}$, chúng tôi cũng không thu được enzyme như mong muốn (Kết quả không được trình bày).

Tinh chế SEGC2 bằng đệm phosphate không chứa $\mathrm{NaCl}$

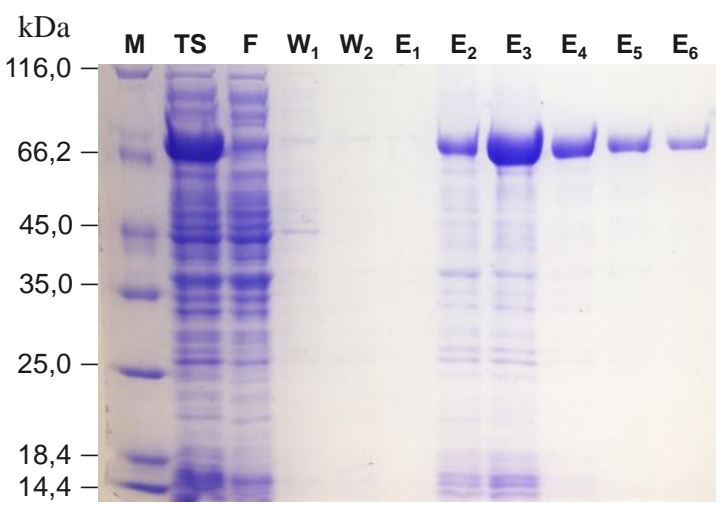

Hình 2. Ảnh minh họa endoglucanase được tinh chế bằng sắc ký ái lực sử dụng đệm phosphate không chứa $\mathrm{NaCl}$

Ghi chú: TS: Protein tổng số pha tan; F: dịch thu trong khi bơm mẫu lên cột; $\mathrm{W}_{1}-\mathrm{W}_{2}$ : lần lượt là dịch rửa cột bằng đệm phosphate chứa 50 và 100 $\mathrm{mM}$ imidazol; $\mathrm{E}_{1}-\mathrm{E}_{6}$ : các phân đoạn thu endoglucanseở nồng độ $300 \mathrm{mM}$ imidazol; M: thang protein chuẩn (Fermentas, SM0431).

Đệm phosphate chứa nồng độ muối cao có thể ảnh hưởng đến ái lực của enzyme với chất giá và cũng ảnh hưởng đến hoạt tính enzyme sau khi tinh chế. Vì vậy, chúng tôi đã thử nghiệm tinh chế $\mathrm{SEGC2}$ bằng đệm không chứa muối $\mathrm{NaCl}$. Mẫu sau khi đưa lên cột được rửa bằng đệm phosphate có chứa 50 và $100 \mathrm{mM}$ imidazol, enzyme được thu lại bằng đệm có chứa $300 \mathrm{mM}$ imidazol. Kết quả so với đệm có chứa $\mathrm{NaCl} 500 \mathrm{mM}$ thì đệm này đã cho khả năng thu hồi enzyme tốt hơn, và enzyme có độ sạch cao hơn (hình 2). Tuy nhiên, hình ảnh điện di cho thấy enzyme vẫn còn lẫn khá nhiều protein khác của chủng chủ mặc dù enzyme trên cột đã được rửa với đệm có chứa nồng độ imidazol tăng dần từ 50 đến cao nhất là $100 \mathrm{mM}$. Với độ sạch này thì enzyme chưa đảm bảo cho nghiên cứu tính chất, do vậy chúng tôi đã thử phương pháp tiếp theo đó là khảo sát tủa phân đoạn muôi amonium phosphate trước khi đưa protein lên cột sắc ký ái lực.

\section{So chế SEGC2 bằng ammonium sulphate và tinh chế bằng sắc ký ái lực His-tag}

Đầu tiên, chúng tôi sơ chế dịch pha tan nhằm loại bớt protein tạp trước khi đưa endoglucanase lên cột sắc ký. Dịch protein tổng số được bổ sung muối $\left(\mathrm{NH}_{4}\right)_{2} \mathrm{SO}_{4}$ tới nồng độ $35 \%$. Sau khi ly tâm loại tủa, pha tan được bồ sung tiếp $\left(\mathrm{NH}_{4}\right)_{2} \mathrm{SO}_{4}$ đến nồng độ $65 \%$. Kết quả điện di protein trên hình $3 \mathrm{a}$ cho thấy khi bố sung $35 \%$ muối, khá nhiều protein tạp đã tủa lại và tách khỏi pha tan chứa SEGC2 (giếng $\mathrm{P}_{35}$ ). Khi nâng nồng độ muối lên $65 \%$, SEGC2 và những protein khác lắng xuống tách khỏi pha tan. Chúng được hòa tan lại bằng đệm gắn mẫu, chứa phần lớn là SEGC2 (giếng $\mathrm{T}_{65}$ ). Dung dịch này được bơm lên cột sắc ký và rửa bằng đệm có chứa từ $50 \mathrm{mM}$ đến $300 \mathrm{mM}$ imidazol. Kết quả cho thấy ở lần tinh chế thứ nhất SEGC2 bám chưa hiệu quả nên một số phân tử bị thôi ra khỏi cột (giếng $\mathrm{F}$ ). Khi nâng đệm có nồng độ imidazol lên $500 \mathrm{mM}$, SEGC2 được thôi ra ở phân đoạn $\mathrm{E}_{1}$ và tập trung nhất ở $\mathrm{E}_{6}-\mathrm{E}_{7}$ (hình $3 \mathrm{a}$ ). Như vậy, bằng phương pháp tủa muối phân đoạn, nhiều protein tạp đã được loại bớt trước khi tiến hành sắc ký ái lực để thu được SEGC2 tái tổ hợp. Tuy nhiên, khi lặp lại quá trình sắc ký này lần thứ hai, chúng tôi nhận thấy rằng hiệu quả thu hồi SEGC2 giảm đi đáng kể, SEGC2 không bám lên cột và phần lớn bị rửa trôi (Giếng $\mathrm{F}$, hình $3 \mathrm{~b}$ ). Do đó, băng SEGC2 ở các phân đoạn $\mathrm{E}_{2}-\mathrm{E}_{9}$ rất mờ nhạt. Hiện tượng này xảy ra tương tự ở các lần tinh chế tiếp theo. Nguyên nhân có thể do các bước tiền xử lý mẫu bằng $\left(\mathrm{NH}_{4}\right)_{2} \mathrm{SO}_{4}$ đã làm cho một số protein ở trạng thái không ổn định, chúng dễ bị tủa và gây ách tắc trong cột, cản trở độ bám của $\mathrm{SEGC2}$. Do đó $\mathrm{SEGC2}$ bị rửa trôi trong lúc bơm mẫu. 


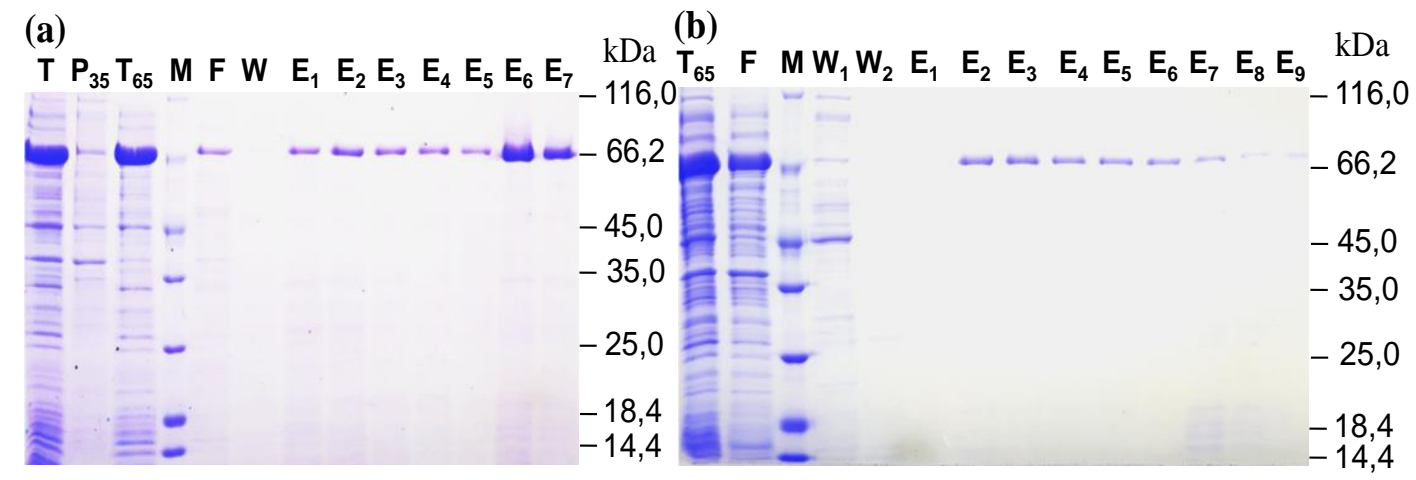

Hình 3. Ảnh minh họa endoglucanase được xử lý bằng muối ammonium sulphate và tinh chế bằng sắc ký ái lực ởlần thứ nhất và thứ hai ( $\mathrm{a}$ và $\mathrm{b}$ )

Ghi chú: M: thang protein chuẩn (Fermentas, SM0431); T: protein ở pha tan; $\mathrm{P}_{35}$ : protein tủa ở nồng độ $35 \%\left(\mathrm{NH}_{4}\right)_{2} \mathrm{SO}_{4} ; \mathrm{T}_{65}$ : protein tủa ở $65 \%\left(\mathrm{NH}_{4}\right)_{2} \mathrm{SO}_{4}$ được hòa tan bằng đệm gắn mẫu; $\mathrm{F}$ : dịch thu trong khi bơm mẫu lên cột; $\mathrm{W}-\mathrm{W}_{1}-\mathrm{W}_{2}$ : lần lượt là dịch rửa cột bằng đệm chứa 50,100 và $300 \mathrm{mM}$ imidazol; $\mathrm{E}_{1}-\mathrm{E}_{9}$ : các phân đoạn thu mẫu bằng đệm chứa $500 \mathrm{mM}$ imidazol.

Tinh chế SEGC2 bằng cột sắc ký ái lực Histag, đệm rửa chứa $150 \mathrm{mM}$ imidazol và đệm thu chứa $400 \mathrm{mM}$ imidazol

Do sơ chế mẫu bằng $\left(\mathrm{NH}_{4}\right)_{2} \mathrm{SO}_{4}$ không hiệu quả nên chúng tôi tinh chế lại endoglucanase bằng cách bơm trực tiếp mẫu lên cột và rửa protein tạp bằng đệm chứa 150 $\mathrm{mM}$ imidazol. Ở lần tinh chế này, $\mathrm{SEGC2}$ bám khá tốt nhưng vẫn còn thôi ra trong lúc bơm mẫu và rửa mẫu (Giếng $\mathrm{F}$ và $\mathrm{W}_{1}$, hình 4a). Khi tăng imidazol lên 400 mM, SEGC2 bị đẩy ra, băng SEGC2 rất tập trung và khá sạch $\left(\mathrm{E}_{2}-\mathrm{E}_{7}\right)$. Quá trình tinh chế này được lặp lại thêm 2 lần vẫn thu được sắc ký đồ tương tự. Như vậy, qua thí nghiệm tinh chế có thể thấy rằng việc tiền xử lý mẫu bằng ammonium sulfate có thể ảnh hưởng đến độ bền của endoglucanase. Enzyme dễ bị tủa và gây ách tắc trong cột. Do đó chúng tôi đã sử dụng đệm chứa imidazol có nồng độ tăng dần từ $300 \mathrm{mM}$ đến $500 \mathrm{mM}$ nhưng enzyme vẫn thôi ra một cách không tập trung (hình 3).

Việc không xử lý mẫu protein tổng số bằng cách tủa muối có thể hạn chế sự thay đổi cấu trúc của enzyme và enzyme ở trạng thái đồng nhất hơn. Do đó, chỉ cần tăng nồng độ imidazol tới $400 \mathrm{mM}$, endoglucanase đã được thôi ra tập trung hơn và thu được nhiều protein hơn (hình $4 \mathrm{a}$ ). Kết quả đánh giá độ sạch của enzyme sau tinh chế bằng phần $m$ ềm
QuantityOne cho thấy enzyme cũng có độ sạch trên 99\% (hình 4b). Như vậy enzyme endoglucanase đã được tinh chế thành công và có độ sạch cao.

Các phân đoạn thu mẫu được gộp lại và loại muôi bằng cột $\mathrm{PD}-10$. Ảnh điện di các phân đoạn sau khi loại muối trên hình $4 \mathrm{c}$ cho thấy băng SEGC2 có độ sạch cao, tập trung dần từ phân đoạn $3-6$ và giảm dần ởphân đoạn 9 (hình 4c). Như vậy, endoglucanase tái tổ hợp đã được tinh chế và loại muối thành công trước khi kiểm tra sơ bộ hoạt tính của enzyme này.

Tinh chế protein là bước cần thiết để có protein tinh sạch làm nguyên liệu cho các nghiên cứu tiếp theo. Tuy nhiên, tùy mục đích có những nghiên cứu tập trung vào tỉnh chế protein, còn số khác lại không quan tâm nhiều đến độ sạch của chúng. Dựa vào đặc điểm và các thiết kế của protein, nghiên cứu tập trung tinh chế chúng theo nhiều cách khác nhau. Wei et al. (2015) đã tinh chế endoglucanase bằng sắc ký trao đổi ion. Tuy nhiên, các tác giả không đề cập đến hiệu suất thu hồi và độ tinh khiêt của enzyme. Amore et al. (2012) cũng tinh chế cellulase tái tổ hợp của Streptomyces G12 sau khi biểu hiện ở Escherichia coli. Trước đó, nhóm tác giả đã tủa cellulase bằng $\left(\mathrm{NH}_{4}\right)_{2} \mathrm{SO}_{4}$ ở nồng độ $80 \%$ bão hòa rồi mới tinh chế thu enzyme bằng sắc 
ký trao đổi ion. Cano-Ramírez et al. (2016) tinh chế endoglucanase tái tổ hợp trực tiếp từ dịch pha tan của tế bào Escherichia coli bằng sắc ký ái lực. Seneesrisakul et al. (2017) lại chỉ xác định hoạt tính thô của endoglucanase tái tổ hợp chứ không tinh chế chúng. Trong nghiên cứu tinh chế endoglucanase tái tổ hợp của mình, chúng tôi từng xử lý loại bớt protein tạp từ dịch protein tổng số rồi mới đưaenzymelên cột. Tuy nhiên, việc làm trên đã không đem lại hiệu quả như mong muốn.
Lý do có thể là một số protein trong mẫu có cấu trúc không bền vững khi tiền xử lý bằng muối $\left(\mathrm{NH}_{4}\right)_{2} \mathrm{SO}_{4}$. Chúng tủa và gây ách tắc cột, ảnh hưởng đến độ bám của enzyme ở các lần tinh chế tiểp theo. Chỉ khi xử lý lại cột và thay đổi cách thức tinh chế, chúng tôi mới thu được endoglucanase tái tổ hợp có độ tinh sạch cao, từ đó có thể đánh giá sơ bộ hoạt tính của cellulase trên cơ chất $\mathrm{CMC}$ hoặc nghiên cứu các tính chất sâu hơn.

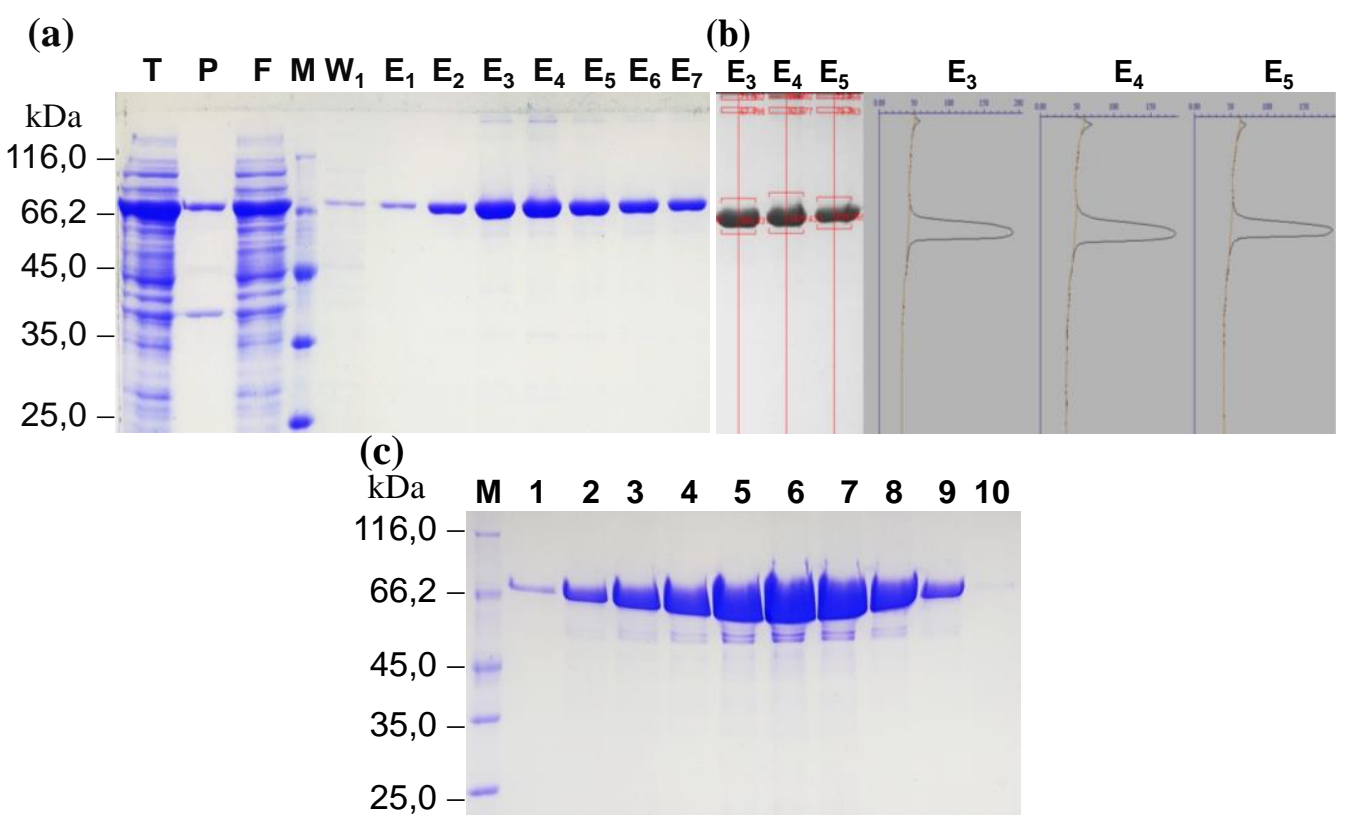

Hình 4. Ảnh minh họa endoglucanase tái tổ hợp được tinh chế trực tiếp từ dịch tổng số pha tan bằng sắc ký ái lực $(\mathrm{a})$, độ tinh sạch của enzyme được đánh giá bằng phân mềm Quantity One (b) và enzyme sau khi loại muối (c)

Ghi chú: M: Thang protein chuẩn (Fermentas, SM0431); T: Protein tổng số pha tan; P: Protein pha tủa; F: dịch thu trong khi bơm mẫu lên cột; $\mathrm{W}_{1}$ : dịch rửa cột bằng đệm chứa $150 \mathrm{mM}$ imidazol; $\mathrm{E}_{1}-\mathrm{E}_{7}$ : các phân đoạn thu mẫu bằng đệm chứa $400 \mathrm{mM}$ imidazol; 1-10: các phân đoạn enzymesau khi loại muối bằng cột PD-10.

\section{Kết quả thử hoạt tính của cellulase tái tổ họ̣p trên đĩa thạch}

Cellulase chủ yếu xúc tác thủy phân mối liên kết $\beta-1,4$ glucoside của cellulose để giải phóng đường glucose. $\mathrm{CMC}$ là một dạng hòa tan của cellulose, được dùng làm cơ chât thử hoạt tính của cellulase. Khi chưa bị thủy phân, CMC bắt màu với thuốc nhuộm Congo tạo thành màu đỏ đồng nhất. Dưới tác dụng của cellulase, vùng CMC bị thủy phân sẽ không bắt màu với thuốc nhuộm nữa, tạo thành $\mathrm{một}$ vòng sáng (halo) có thể quan sát bằng mắt thường. Kết quả thử hoạt tính của ba mẫu gồm đối chứng dương (cellulase của Sigma), đối chứng âm (dịch pha tan của chủng mang gen không cảm ứng IPTG) và endoglucanasesau khi tinh chế và loại muối trên đĩa thạch chứa CMC đã cho thấy quanh giếng EGC2 (E) xuất hiện vòng thủy phân màu sáng giống như ở 
giếng đối chứng dương (+) mặc dù đường kính vòng phân giải không lớn bằng (hình 5 ). Trong khi đó ở mẫu đối chứng âm (-) không có vòng thủy phân này. Như vậy, có thể khẳng định endoglucanase tái tổ hợp thu được có hoạt tính thủy phân cơ chất CMC.

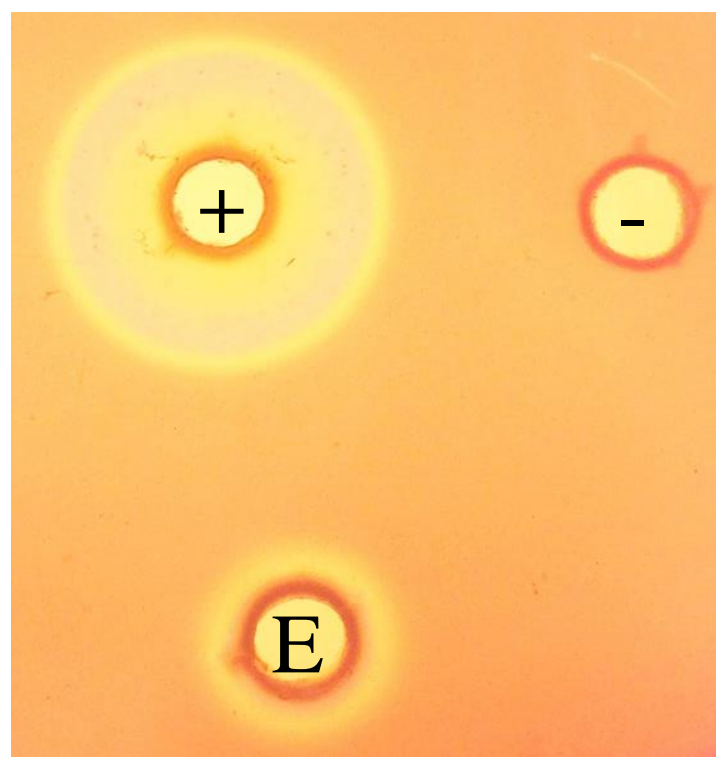

Hình 5. Ảnh thử hoạt tính của endoglucanase tái tổ hợp trên đĩa thạch chứa cơ chất $\mathrm{CMC}$ bằng phương pháp nhuộm Congo red Ghi chú: (+): Cellulase của Sigma (1 U); (-): Dịch pha tan của chủng tái tổ hợp không cảm ứng IPTG; (E): endoglucanase tái tổ hợp.

Kết quả thử hoạt tính ở trên cũng giống với các nghiên cứu khác về cellulase tái tổ hợp biểu hiện ở vi khuẩn của Pandey et $\mathrm{al}$. (2014), Seneesrisakul et al. (2017). Trong nghiên cứu này, chúng tôi chưa đánh giá được hoạt tính củaenzyme cao hay thấp, enzyme có bền nhiệt không, hoạt động tốt trong điều kiện axit hay kiềm và có ảnh hưởng thế nào đến các vùng chưa biết chức năng của enzyme. Những đặc điểm này sẽ được nghiên cứu kỹ hơn trong thời gian tới.

\section{KẾT LUẬN}

Chúng tôi đã tinh chế được endoglucanase tái tổ hợp có nguồn gốc từ hệ vi khuẩn sống trong dạ cỏ dê ở tế bào Escherichia coli Rosetta2 bằng sắc ký ái lực. Enzyme thu hồi có độ tinh sạch lên tới 99\%. Sau khi loại muối, endoglucanase đã thể hiện hoạt tính thủy phân cơ chất CMC. Kết quả trên là cơ sở để nghiên cứu sâu hơn về endoglucanase tái tổ hợp nhằm định hướng cho ứng dụng của enzyme tái tổ hợp trong thực tiễn.

Lời cảm ơn: Bài báo được thực hiện từ nguồn kinh phí của đề tài cấp Viện Hàn lâm Khoa học và Công nghệ Việt Nam "Nghiên cứu vai trò của vùng chưa biết chức năng trong cấu trúc module của cellulase" giai đoạn 2018-2019 do TS. Đỗ Thị Huyền, Viện Công nghệ sinh học chủ nhiệm. Công trình có sử dụng trang thiết bị của Phòng thí nghiệm Trọng điểm Công nghệ gen tại Viện Công nghệ sinh học, Viện Hàn lâm Khoa học và Công nghệ Việt Nam (VAST).

\section{TÀI LIỆU THAM KHẢO}

Amore A., Pepe O., Ventorino V., Birolo L., Giangrande C., Faraco V., 2012. Cloning and recombinant expression of a cellulase from the cellulolytic strain Streptomyces sp. G12 isolated from compost. Microb. Cell Factories, 11: 164.

Cano-Ramírez C., Santiago-Hernández A., Rivera-Orduña F.N., García-Huante Y., Zúñiga G., Hidalgo-Lara M.E., 2016. Expression, purification and characterization of an endoglucanase from Serratia proteamaculans CDBB-1961, isolated from the gut of Dendroctonus adjunctus (Coleoptera: Scolytinae). AMB Express6.

Chuan Wei K.S., Teoh T.C., Koshy P., Salmah I., Zainudin A., 2015. Cloning, expression and characterization of the endoglucanase gene from Bacillus subtilis UMC7 isolated from the gut of the indigenous termite Macrotermes malaccensis in Escherichia coli. Electron.J. Biotechnol., 18: 103-109.

Lynd L.R., Weimer P.J., van Zyl W.H., Pretorius I. S.,2002. Microbial cellulose utilization: fundamentals and biotechnology. Microbiol. Mol. Biol. Rev. MMBR, 66: 506-577.

Maki M., Leung K.T., Qin W., 2009. The prospects of cellulase-producing bacteria 
for the bioconversion of lignocellulosic biomass. Int. J. Biol. Sci., 5: 500-516.

Nguyen K.H.V., Nguyen T.T., Truong N.H., Do T.H., 2019. Application of bioinformatic tools for prediction of active $\mathrm{pH}$ and temperature stability of endoglucanases based on coding sequences from metagenomic DNA data. Biological Forum, 11: 14-20.

Nguyen T.Q., Duong T.H., Dang T.N.H., Le N.G., Le Q.G., Do T.H., Nguyen V.D., Le T.T.H., Truong N.H., 2018. Enhanced soluble expression and efective purification of recombinant human interleukin-11 by SUMO fusion in
Escherichia coli. Indian Journal of Biotechnology, 17: 579-585.

Pandey S., Kushwah J., Tiwari R., Kumar R., Somvanshi V.S., Nain L., Saxena A.K., 2014. Cloning and expression of $\beta-1,4-$ endoglucanase gene from Bacillus subtilis isolated from soil long term irrigated with effluents of paper and pulp mill. Microbiol. Res., 169: 693-698.

Seneesrisakul K., Guralp S.A., Gulari E., Chavadej S., 2017. Escherichia coli expressing endoglucanase gene from Thai higher termite bacteria for enzymatic and microbial hydrolysis of cellulosic materials. Electron. J. Biotechnol., 27: 70-79. 